\title{
The impact of human forest disturbance on the endemic avifauna of the Udzungwa Mountains, Tanzania
}

\author{
JON FJELDSA
}

\begin{abstract}
Summary
Studies of how avian communities are affected by human forest disturbance have given variable results. In order to focus conservation efforts we need comparative data for studying the relationship between community resilience and ecological predictability over much longer periods of time. This paper compares avian communities in mature forest and adjacent disturbed forest at a site in the Tanzania-Malawi Mountains which has probably had humid forest cover permanently since the Tertiary. At the same time the study presents a possible model design for such studies, which may be a suitable compromise between the needs for quantitative data and logistical constraints during exploratory visits to areas difficult of access. The method is highly time efficient as it is based on continuous recording of all birds during "random" walking through the forest. There were at least 70 species in disturbed, against $61-65$ species in different kinds of adjacent mature forest, but with a marked loss of range-restricted species as we passed from mature to disturbed forest. Most seriously affected were birds of the shaded forest understorey, but also the larger insectivores of mixed canopy feeding parties declined. These species search for food in the masses of epiphytic lichens, mosses and ferns in mature forest canopies. Comments are given on the specific requirements of six species of conservation concern.
\end{abstract}

\section{Introduction}

Despite the strong attention to how forest bird communities in the tropics are affected by human habitat disturbance (see Laurance and Bierregaard 1997 for review), the lessons learned are unclear and to some extent contradictory. The divergence of conclusions is difficult to interpret because of different project designs and because the habitat modifications were often described in very general terms (see Danielsen 1997). However, when comparing comprehensive studies in areas where the logging histories were well documented it is apparent that different avifaunas respond quite differently to a specific disturbance. C. Dranzoa (1996, unpubl. PhD thesis, Makerere University), working in south-west Uganda, found marked negative effects of past selective logging, while L. Holbeck (1996, unpubl. PhD thesis, University of Copenhagen), working in Ghana, found very slight effects. This kind of variation could reflect the amount of habitat disturbance in the more distant past (Balmford 1996). Long histories of human settlement, as well as pre-human environmental change (Danielsen 1997) may have acted as extinction filters, leading to resilient communities. One may therefore 
expect forest bird communities of areas which were permanently forest-covered during the Pleistocene (e.g. near the "Central African Forest Refuge", Hamilton 1982) to be more sensitive to change than those where forest and savanna conditions alternated (e.g. Ghana, see Hamilton 1982, Maley 1989, Nicholson 1994). Differences in community resilience would be related to the life history adaptations of individual species, which were moulded by long-term ecological predictability.

Unfortunately, because of the variation in study designs, the existing data do not permit robust testing of such generalizations (see Danielsen 1997 and references therein). Because of their potential implications for focusing conservation efforts (see Balmford 1996), the problem needs to be approached in a more systematic way (Fjeldså and Lovett 1997). The needs for good comparative data from many well-chosen geographical sites require standardized and rapid assessments. The present study will describe marked differences between adjacent mature and disturbed forest habitats in an area which may have had humid forest permanently since the Tertiary. At the same time it represents a possible model design for such studies, which may strike a suitable balance between the needs for reliable quantitative data and the logistical constraints involved when working in tropical forest, including areas of difficult access.

\section{Study area}

The study area was in the Udzungwa Mountains in the Eastern Arc Mountains of Tanzania. Originating by block faulting over a long geological period, these mountains appear today as a chain of isolated "forest islands" that rise steeply 1-2 km above the "ocean" of savanna plains (see Lovett and Wasser 1993). The east-facing scarps are under direct climatic influence from the Indian Ocean, which had an exceptionally stable temperature during the Pleistocene (Prell et al. 1980). The East Usambara Mountains, situated near the coast, and the high eastfacing escarpments of the Uluguru and Udzungwa Mountains may have been permanently covered by humid forest since the Tertiary, as evidenced by the aggregation of endemic species of various taxonomic groups (Lovett and Wasser 1993, Burgess et al. in press a; see Dinesen et al. 1993 and Stattersfield et al. 1998 for birds). Also, these places are characterized by a high present-day ecoclimatic stability (Fjeldså et al. 1997).

The Udzungwa mountains constitute the largest highland in the Eastern Arc, with $1,360 \mathrm{~km}^{2}$ of natural highland forest, including many areas of minimal human impact. The Hehe tribe, which inhabits the highland, cleared forest for agriculture for certainly more than 100 years (Lovett and Congdon 1989). Many plateau forests are therefore of secondary nature (J. Lovett and D. Moyer pers. comm.; these are the "dry" forests of Stuart et al. 1981). However, the impact of the "first assault" by man can be studied today in the large forest tracts near the scarp.

The study was done in October-November 1996 from a base camp at Kihanga $\left(8^{\circ} 22^{\prime} 6^{\prime \prime} \mathrm{S}, 35^{\circ} 58^{\prime} 25^{\prime \prime} \mathrm{E}\right)$ in the Uzungwa Scarp Catchment Forest Reserve (note that the modern change of spelling from Uzungwa to Udzungwa is not implemented in the official name of this reserve). The reserve covers 20,000 ha, of which a $5-\mathrm{km}$-wide zone of highland forest along the northern part of the scarp 
may be regarded as primary forest. Here, the only human activity is low-intensity hunting and cutting of occasional trees which have honey or tree hyrax (Dendrohyrax) roosts. The area has an estimated rainfall of $2,000 \mathrm{~mm}$ per year with a strong mist effect in addition (Lovett and Pócs 1993).

A plateau-like area at $1,700-1,800 \mathrm{~m}$ (called Hill Zone in the following) is dominated by $40-\mathrm{m}$-tall trees (primarily Bridelia sp., Cleistanthus polystachus, Ficalhoa sp., Macaranga sp., Myrianthus holstii, Parinari excelsa, Rapanea sp. and Syzygium sp., locally Allanblackia sp.) and has an almost unbroken canopy in most parts. The forest has large amounts of epiphytes, notably lichens (Usnea). The surface is rugged. The highest parts of the terrain are characterized by high species diversity of trees and a very high basal area (J.D. Mremi, pers. comm.) and an open understorey of grasses and ferns. The lower parts have many small understorey trees (Rauvolfia mannii, Tabernemontana sp., many Rubiaceae and in some places Bersema sp.) and small glades with thick herbaceous vegetation (Impatiens sp., Leucas densiflora, Mimulopsis sp., Piper capensis, Psychotria sp., Solanum sp.) along the streams. The plateau-like area gives way to well-defined valleys with many steep $\left(30-45^{\circ}\right)$ slopes and turbulent steams (1,500-1,700 m; Valley Zone in the following), and 100 to $200-\mathrm{m}$-high waterfalls leading into deep submontane gorges. In this zone, some trees are more than $50 \mathrm{~m}$ tall, but there are also several light gaps of up to a few hectares in extent (Fig. 1a), as fast-growing trees (e.g. Anthocleista grandiflora) growing on hydromorphic soils often die standing, giving way to thick herbaceous vegetation which prevents colonization by new trees. Thus, topographical complexity and natural successional processes add to the heterogeneity of the forest.

The north-western part of the forest reserve, adjacent to the upland village of Masisiwe ( $\left.81^{\circ} 8^{\prime} \mathrm{S} 35^{\circ} 54^{\prime} 30^{\prime \prime} \mathrm{E}\right)$ has been strongly modified in the past by settlement inside previously forested areas. Over c. $50 \mathrm{~km}^{2}$, the forest was fragmented by establishment of small fields (shambas), shifting cultivation and selective logging. The people were moved out of the forest area in about 1910 as the Ruaha stream was defined to form the boundary of the newly established forest reserve. Selective logging continued for a long time, but has now ceased completely. However, the regeneration of forest trees is very slow (G. Moshi, pers. comm.). The highest hills $(1,700-2,000 \mathrm{~m}$, in the background in Fig. $1 \mathrm{~b})$ are now covered in bamboo forest Sinarundinaria alpina with a short ground cover of grasses and a few herbaceous species, and very scattered bushes and trees. In a 1 to $2-\mathrm{km}$ transition zone between the bamboo zone and the mature forest occasional fires (see fire scars in Fig. 1b) maintain an intricate mosaic: glades (with bracken Pteridium aquilinum, brambles Rubus sp. and tall herbs), bamboo stands, forest patches dominated by small trees and bushes of pioneer species (Macaranga sp., Myrica salicifolia, Polyscias fulva, often with many mistletoes) and a few large epiphyterich trees of the fire-resistant Aguaria salicifolia. Most fires may be lit by people, probably to maintain an open view along the two trails that pass through the area. Although such fires may not kill well-grown trees they certainly hamper the regeneration of new trees. The forest patches are partly connected, but the patch structure is such that all forest habitat is less than $100 \mathrm{~m}$ away from a bamboo or herbaceous "matrix".

Further south in the Uzungwa Scarp Forest Reserve, the forest is moderately disturbed by logging, with many areas of bushy or herbaceous vegetation. The 


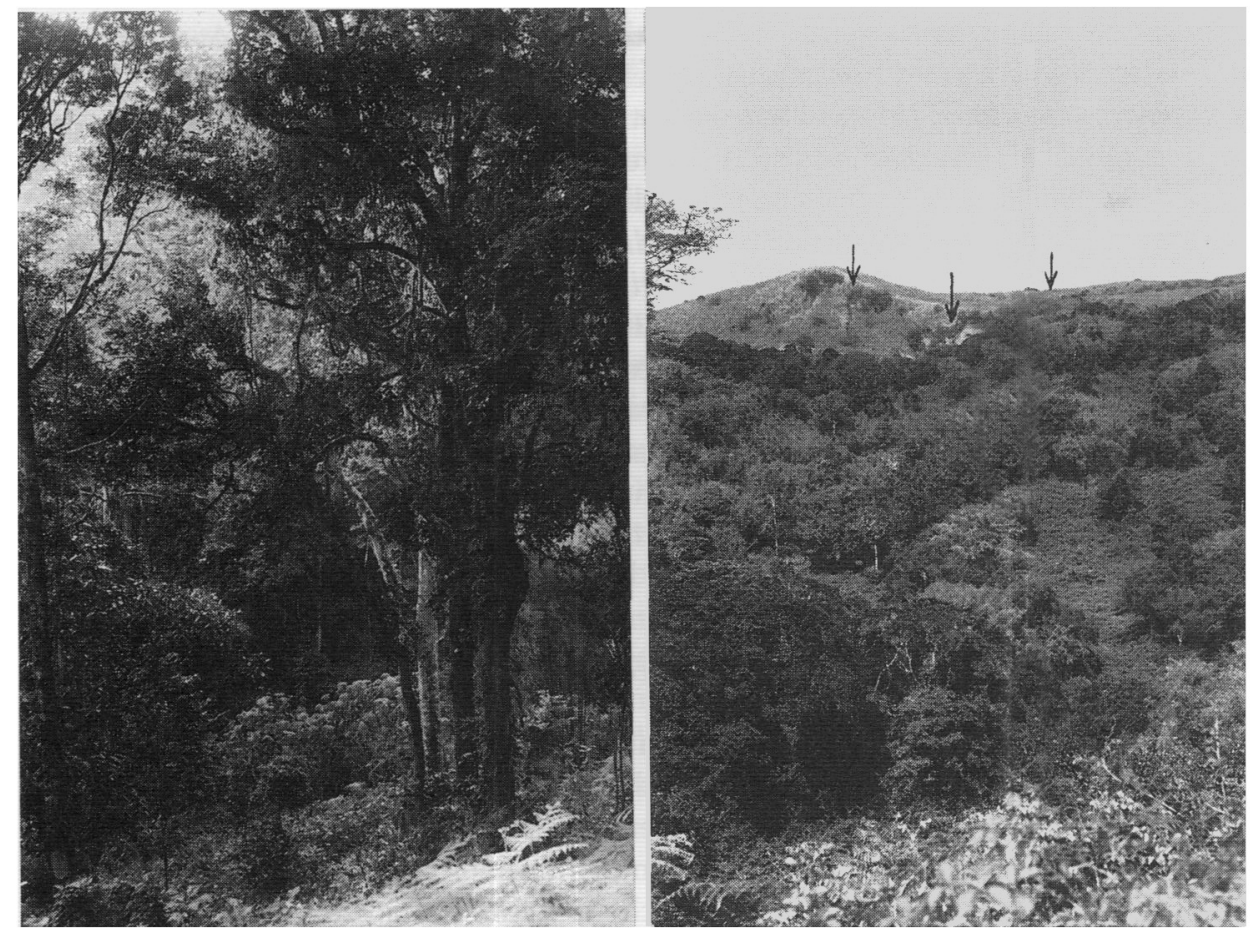

Figure 1. Mature forest (a) and adjacent disturbed habitat mosaic (b) in the Uzungwa Scarp Forest Reserve. (a) Trees $45 \mathrm{~m}$ tall on the edge of a glade at $1,650 \mathrm{~m}$ with thick herbaceous vegetation and flowering composite bushes. Conservation-dependent species such as Dappled Mountain Robin Arcanator orustruthus, Iringa Akalat Sheppardia lowei, Rufous-winged Sunbird Nectarinia rufipennis and Usambara Weaver Ploceus nicolli were all recorded in this place. (b) A mosaic of small woodland patches, bamboo areas and glades with tall herbaceous vegetation, and extensive bamboo forest with scattered trees in the high hills (to 2,000 $\mathrm{m}$ ) in the background. Arrows mark fire scars surrounded by bamboo with dead (pale) foliage.

forest at Uhafiwa $\left(8^{\circ} 31^{\prime} \mathrm{S} 35^{\circ} 51^{\prime} \mathrm{E}, 1,415^{-1,500 \mathrm{~m})}\right.$ is dense but not very tall, with some swampy areas, thickets and liana tangles, and may be secondary, judging from old cultivation mounds on the forest floor (Moyer 1993). Some comparative remarks will be made on this area, with reference to the detailed ornithological study by D. Moyer (op. cit.). Also some areas of monospecific forest of Felicium decipiens, at $1000-1200 \mathrm{~m}$, could be second growth on former cultivation (Lovett et al. 1997).

\section{Methods}

Avian species richness was determined using a modified "20-species method" (McKinnon and Phillips 1993; see Poulsen et al. 1997). During slow and quiet walking within a study plot of c. $1.5 \mathrm{~km}^{2}$ in extent all bird identifications were noted from sunrise to sunset with brief notes describing unidentified birds (or vocalizations) to allow later adjustments. Subsequently the number of species 


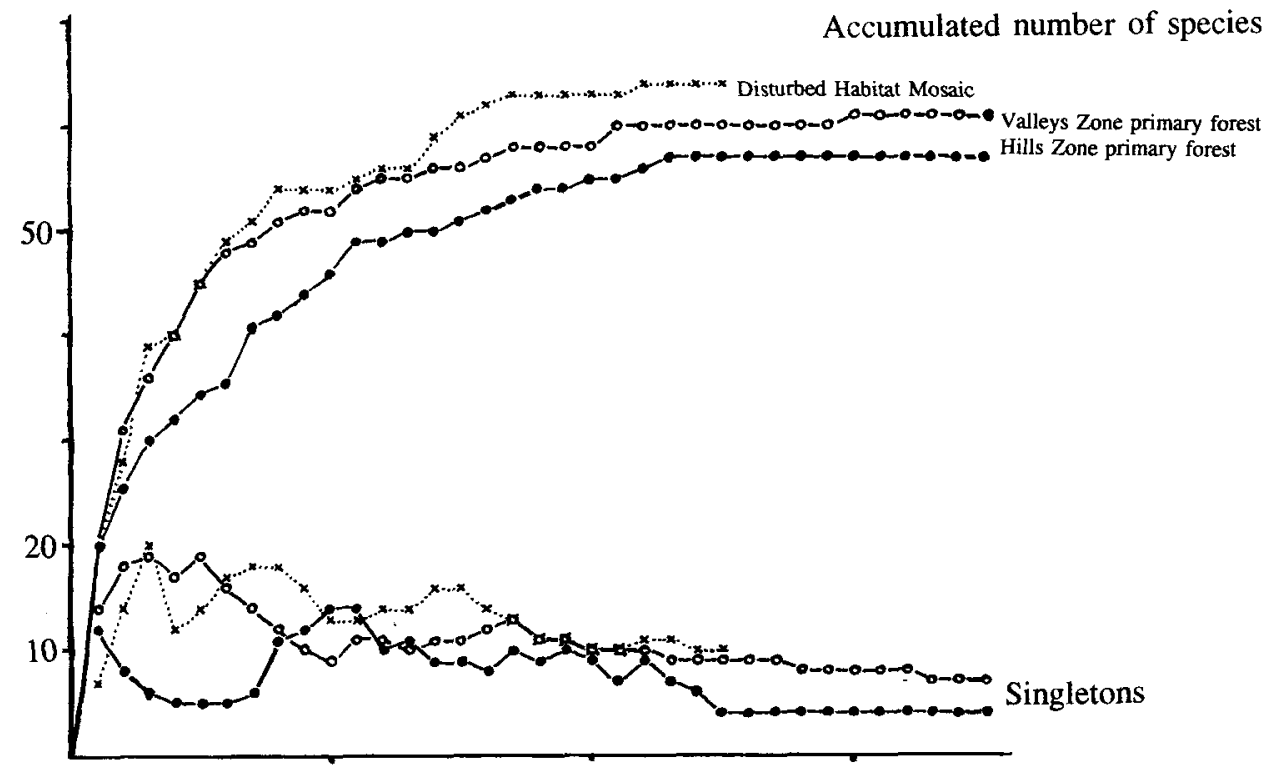

Figure 2. Accumulated numbers of species and singletons (species recorded only once) as a function of the number of 20-species lists compiled. Data from primary forest hills, at $1,700-1,800 \mathrm{~m}$, mainly closed forest on non-hydromorphic soils (0); primary forest in valleys and steep hills, at 1,500-1,700 $\mathrm{m}$, with some natural glades with hydromorphic soils (O); and adjacent areas of disturbed forest, at $1,700-1,800 \mathrm{~m}$, which are part of a mosaic habitat as shown in Fig. $1 \mathrm{~b}(\mathrm{x})$.

was counted, up to 20 species; then a new sublist of 20 species was compiled, and so on. Accumulation graphs were then drawn showing the total number of species as a function of the number of 20-species lists compiled. These graphs suggest a stabilization after $>30$ lists have been compiled (Figure 2). In simple surveys it is important that this Observed Species Richness is not used to mean Total Species Richness. The latter can be estimated from the full list of observations using Chao I (see Colwell and Coddington 1994) $S_{1}=S_{o b s}+a^{2} / 2 b$, where $S_{o b s}$ is the number of species recorded, a the number of singletons (number of species recorded only once), $b$ the number of doubletons. The variance of the estimated richness value is $\operatorname{var}\left(S_{1}{ }^{*}\right)=b\left[(a / b)^{4} / 4+(a / b)^{3}+(a / b)^{2} / 2\right]$.

Poulsen et al. (1997) suggest use of the incidence of the individual species on such lists to characterize the community structure. For a methodological control the data were compared with results of the more time-consuming but welldocumented counts on 50 independent 1-ha plots in each of the two mature forest habitats (namely timed points counts with a fixed area, see Fjeldså and Rabel 1995). This comparison revealed that incidence values severely underscore some common species which are redundantly represented on many 20-species lists. However, if instead all individual bird identifications made during "random walking" were summed up (omitting birds which were more than 50 m away or recorded in the twilight periods, when only certain species sing), the percentage abundance of each species is closely correlated with that obtained using point counts $\left(r_{s} 0.969, P<0.001\right.$ and $r_{s} 0.888, P<0.001$ for Hill and Valley 
Zones, respectively). Accordingly, data gathered during "random walking" are probably not more biased than other observational methods, such as point counts.

The advantages of the approach are (1) high time efficiency, as the entire available time period is used to produce data, unlike when using point counts, transects, etc.; (2) a possibility to standardize the data and extrapolate Total Species Richness, compared with just recording a total list of species seen; (3) a fairly reliable record of the relative abundances of individual species; and (4) relative observer independence, compared with timed species count method. Only territory mapping will give decidedly better results, but this method is too time consuming (see Terborgh et al. 1990) to be widely useful for comparative studies in tropical forests. The method is certainly much more complete and much less biased than mist-netting (see Remsen and Good 1996).

Data were collected in three ecological zones: in Valley Zone mature forest (802 bird identifications producing 35 20-species lists; 647 identifications on 50 point counts used as a "control"), in Hill Zone mature forest (1080 identifications producing 35 20-species lists; 458 identification on 50 point counts for a "control"), and in disturbed forest mosaic (always within $1 \mathrm{~km}$ of mature forest, 670 identifications producing 2520 -species lists). The record of species richness is probably quite complete in terms of "core species" but not for migrants or overflying raptors, waterbirds, etc.

For the evaluation of conservation needs, special attention was given to species of restricted distribution: their range restrictetness was scored using a database in the WorldMap computer program (Williams 1994) where all African breeding birds have been mapped to $1^{\circ}$ spatial resolution (see Burgess et al. in press $a, b$ ). A "range-size rarity score" was used (Usher 1986, Williams 1994), which is the inverse range size of each species in relation to the average range-size for all species, in this case 316 grid cells.

\section{The bird community of mature forest habitats}

In the Hill Zone mature forest, the species accumulation curve stabilized at 57 species. Chao I estimated 59 species (S.D. \pm 1.5 ), but inclusion of records in mistnets and by other observers gave a total of 61 species. In the Valley Zone mature forest, which is a more heterogeneous habitat with some open, herbaceous areas, the species accumulation curve levelled out at 61 species (Figure 2). Chao I estimated 65 species (S.D. \pm 4.4 ). E. Mulungu saw one additional forest species and three additional species were seen in a large landslide gap, providing empirical evidence for 65 species.

The Yellow-streaked Greenbul Phyllastrephus flavostriatus was the commonest species followed by Waller's Chestnut-winged Starling Onychognathus walleri, which were feeding, in flocks or pairs, in high canopies all over the forest. A large proportion of the birds participated in mixed feeding parties, which were mainly of two types: either species-rich assemblies around a pair of Square-tailed Drongo Dicrurus ludwigii, or a relatively smaller number of species following noisy parties of Yellow-streaked Greenbul. In addition, special understorey groups with Olive Mountain Greenbul Phyllastrephus cabanisi and a few other birds were sometimes recorded. The two first kinds of parties tend to remain for 
long periods in well-illuminated places, such as in tall epiphyte-rich trees on the edge of a natural forest glade.

The relative abundances of individual species in the Valley and Hill Zones are well correlated (Figure 3a; $r_{s} 0.802, P<0.001$ ). However, Sharpe's Akalat Sheppardia sharpei, Swynnerton's Robin Swynnertonia swynnertoni, Dappled Mountain Robin Arcanator orostruthus and White-chested Alethe Alethe fuelleborni (which all prefer tall-growth forest), and the high-altitude species Olive Pigeon Columba arquatrix and Bar-throated Apalis Apalis thoracica were relatively most abundant in the Hill Zone. Evergreen and Red-capped Forest Warblers, Bradypterus mariae and Orthotomus metopias (in herbaceous glades), Spotthroat Modulatrix stictigula (in dense thickets near streams), White-starred Forest Robin Pogonocichla stellata and Black-capped Apalis Apalis melanocephala (habitat generalists) were more abundant in the Valley Zone.

\section{The bird community of disturbed mosaic habitats}

Twenty-five 20-species lists gave 64 species. Chao I estimated 70 species (S.D. \pm 5.3). The area had some ubiquitous species, such as Tambourine Dove Turtur tympanistra, Black-backed Puffback Dryoscopus cubla, Common Bulbul Pycnonotus barbatus and Collared Sunbird Anthreptes collaris. Some non-forest species were seen in the larger glades, such as Mountain Yellow Warbler Chloropeta similis, Cinnamon Bracken-warbler Bradypterus cinnamomea, Yellow-bellied Waxbills Estrilda melanotis and even one Green-winged Pytilia Pytilia melba. Five additional species (two of them overflying migrants) were seen outside the study plot in the same ecological zone, suggesting that the total species richness could well be more than the estimated 70 species. Thus, because of the existence of non-forest birds, the total species richness was' higher than in the mature forest. However, the mean range-size rarity for 12 species found only in the disturbed zone was 5.8 , compared with the mean range-size rarity score 32.9 for 11 species found in the Hill Zone mature forest but not in the disturbed zone ( $t$-test after logarithmic transformation gives $t=3.028, P<0.01$ ).

The commonest species in the disturbed zone was the Mountain Greenbul Andropadus tephrolaemus, which was particularly abundant at edges with many brambles. This species was followed by Moustached Green Tinkerbird Pogoniulus leucomystax, Evergreen Forest Warbler and Fuelleborn's Black Boubou Laniarius fuelleborni. Common birds in the forest patches were Olive Pigeon, Lemon Pigeon Columba larvata, Livingstone's Tauraco Tauraco (persa) livingstonii and Whitestarred Forest Robin. Large numbers of Black Saw-wings Psalidoprocne pristoptera (two subspecies) were feeding over the larger glades. The Oriole Finch Linurgus olivaceus was locally common on steep herbaceous slopes near forest edges.

Figure $3 b$ illustrates an almost inverse relationship between the communities inhabiting disturbed and mature forest $\left(r_{s} 0.073\right.$, N.S.). Only Green Barbet Stactolaema olivacea and Silvery-cheeked Hornbill Bycanistes brevis were fairly uniformly distributed across the boundary between the two habitats. Nearly all other species fall near one axis or the other, which means that they are associated with either mature forest or disturbed habitat. It is remarkable that, although mixed feeding parties frequented light-gap borders in the primary forest, they were absent from adjacent disturbed forest (note the position of Square-tailed Drongo 
Jon Fjeldså

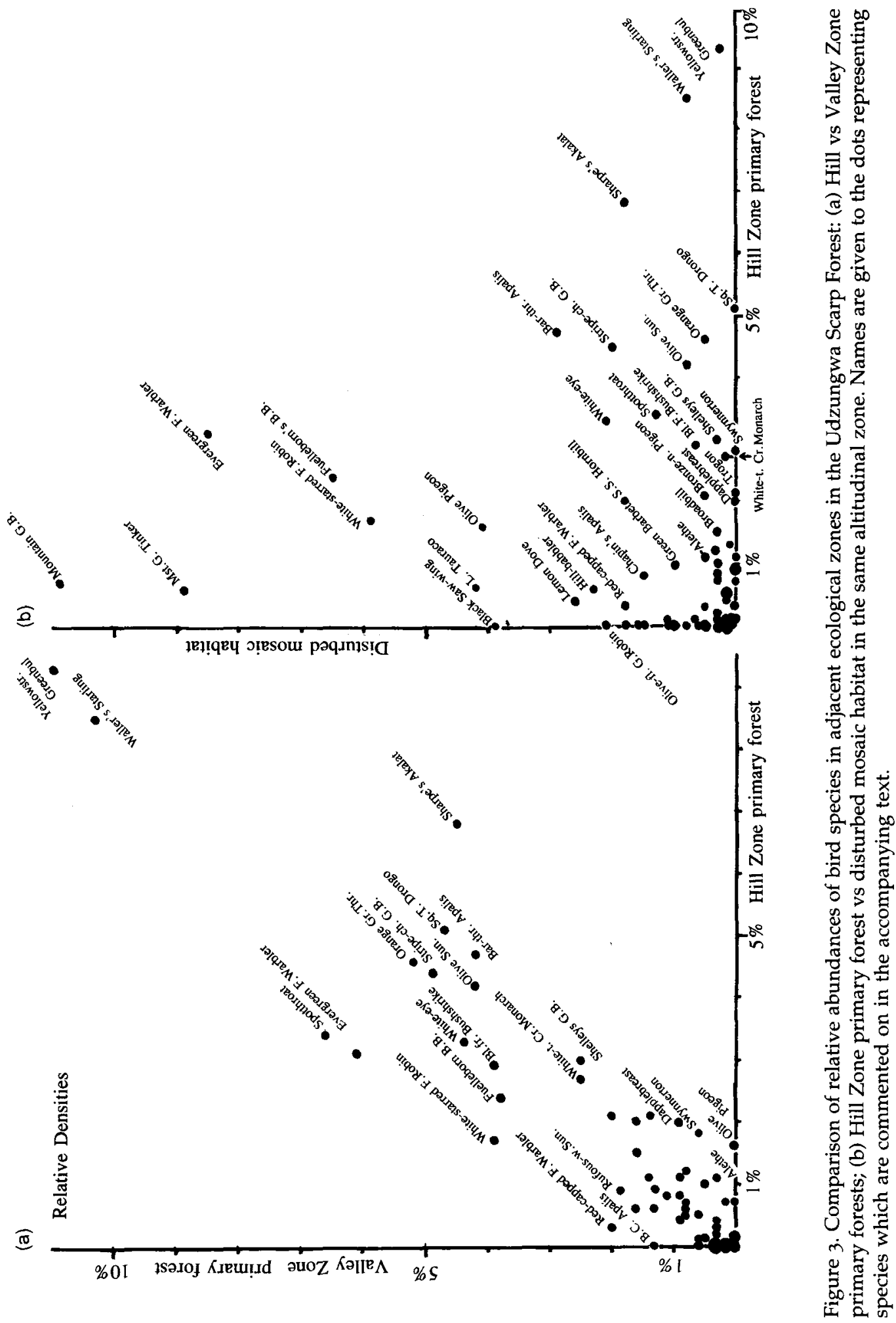


and Yellow-streaked Greenbul near the primary forest axis in Figure $3 \mathrm{~b}$ ). The Bar-tailed Trogon Apaloderma vittata and White-tailed Crested Monarch Trochocercus albonotatus, Swynnerton's Robin and Rufous-winged Sunbird Nectarinia rufipennis were also absent from the disturbed zone. Other interior forest species (Orange Ground-thrush Zoothera gurneyi, African Broadbill, Dappled Mountain Robin, White-chested Alethe) were found only very locally in the disturbed zone.

\section{The bird community of pure bamboo stands}

The bamboo-covered hills had very few birds (see Cloudsley-Thompson 1969: 131), both in absolute numbers and in terms of species richness (Fuelleborn's Black Boubou, White-starred Forest Robin, Evergreen Forest Warbler, Barthroated Apalis, and tinkerbirds, the latter associated with scattered groups of trees). Olive-flanked Ground Robin was common in scrubby edges towards bracken areas and in swampy valley bottoms.

\section{Comparative remarks on the Uhafiwa secondary forest}

Using territory-mapping, Moyer (1993) found a similar fauna as described above for mature forest, in the well-regenerated secondary forest at Uhafiwa. He found dense populations of several endemic forest birds: Fuelleborn's Black Boubou, Spotthroat, Dappled Mountain Robin, Swynnerton's Robin, Sharpe's Akalat, Rufous-capped Warbler, and moderately dense populations of Iringa Akalat Sheppardia lowei, White-winged and Chapin's Apalis, Apalis chariessa and (porphyrolaema) chapini. However, Rufous-winged Sunbird is unrecorded.

A very high density of Tambourine Dove, Little Greenbul Andropadus virens, Yellow-rumped Tinkerbird Pogoniulus bilineatus and Black-headed Apalis, and rare (seasonal) visits by Olive Pigeon and Mountain Greenbul, may reflect the low altitude of Uhafiwa. The site resembles the disturbed habitat mosaic near Masisive in having very high densities of Evergreen Forest Warbler, relatively high densities of Lemon Dove, Moustached Green Tinkerbird, and some Cinnamon Bracken Warbler, Black-backed Puff-backs and Collared Sunbirds.

\section{Guild structure}

Table 1 summarizes the number of specimens in some broad trophic categories, which were defined according to a breakdown of guild structure. The structure of the Disturbed Zone avifauna differed significantly from the adjacent Hills Zone mature forest (one-tailed $\chi^{2}$ test $=965.6, P<0.001$ ). The number of small insectivorous birds, and of generalized feeders (insects and fruit) was approximately the same across habitats. There was a slight reduction in numbers of small birds with mixed nectar/insect diet in the disturbed zone and a marked decline in the number of larger insectivores, comprising understorey species (such as Orange Ground-thrush, Spotthroat, Swynnerton's Robin, Dappled Mountain Robin and White-chested Alethe) as well as canopy species (Square-tailed Drongo, Shelley's Greenbul and Phyllastrephus greenbuls; Figure 3b). The number of specialized frugivores clearly peaked in the disturbed area. This was mainly due to an increase in the number of tinkerbirds (which mainly feed on mistletoe 
Table 1. Species richness and accumulated range-size rarity scores and individuals representing different tropic subdivisions (calculated for 1,000 individuals in the community): small birds with mixed diet of nectar/arthropods, small birds with mainly an arthropod diet, larger (>4० g) predatory birds, birds with a mixed diet of arthropods and small fruits, and birds which are mainly frugivorous (based on information in regional handbooks)

\begin{tabular}{lccc}
\hline & \multicolumn{2}{c}{ Primary forest } & \\
\cline { 2 - 4 } & $\begin{array}{c}\text { Valley Zone } \\
1,500-1,700 \mathrm{~m}\end{array}$ & $\begin{array}{c}\text { Hills Zone } \\
1,700-1,800 \mathrm{~m}\end{array}$ & $\begin{array}{c}\text { Disturbed zone } \\
1,700-1,800 \mathrm{~m}\end{array}$ \\
\hline No. of species (estimate) & $65 \pm 4.4$ & $59 \pm 1.5$ & $70 \pm 5.3$ \\
No. of genuine forest species & 55 & 49 & 41 \\
Range-size rarity sum & 7841 & 9393 & 5841 \\
Mixed insects/nectar & 97 & 84 & 49 \\
Small insectivores & 309 & 307 & 344 \\
Large insectivores & 306 & 330 & 98 \\
Insects/berries & 228 & 213 & 193 \\
Frugivores & 58 & 66 & 315 \\
\hline
\end{tabular}

fruits), tauracos and pigeons, while Green Barbets and hornbills were rather evenly distributed.

The summed range-size rarity score (calculated per 1,000 individual birds) in the community was $61 \%$ higher in the Hill Zone mature forest than in the disturbed mosaic habitat. The high range-size rarity scores in the mature forest was mainly caused by high densities of Shelley's Greenbul, Sharpe's Akalat, Swynnerton's Robin, Spotthroat and Dappled Mountain Robin, and a fairly high density of Rufous-winged Sunbird. Among restricted-range species, only Redcapped Forest Warbler and the Udzungwa Mountain Greenbul (ssp. chlorigula, see Roy et al. 1998 for taxonomic rank) contributed significantly in the disturbed zone.

\section{Comments on species of conservation concern}

\section{Dappled Mountain Robin}

Vulnerable, with a small but highly disjunct range within the Tanzania-Malawi mountains (Stattersfield et al. 1998). It requires shady places below a closed canopy, often places with large amounts of dead leaves on the forest floor among Aframommum and Cyperus on low parts of steep slopes, but also near hilltops. It was quite common in mature forest, up to $1,800 \mathrm{~m}$ (a slight altitudinal record, see Dinesen et al. 1993) and in well-developed secondary forest at Uhafiwa. It was absent from the disturbed habitat mosaic and bamboo zone towards Masisiwe. Although this species is much commoner in the Udzungwa mountains than believed before (Stuart and Turner 1980, Moyer 1993), its long-term persistence certainly depends on how the forests will be managed in the future.

\section{Swynnerton's Robin}

Vulnerable, with a small but highly disjunct range (Dinesen et al. 1993). This species is narrowly associated with closed forest, often fairly well-drained slopes 
with many fallen logs, a thick layer of dead leaves and some Dracaena. It was found to $1,800 \mathrm{~m}$ (a slight altitudinal extension, see Dinesen et al. 1993). There is a good population at Uhafiwa, but it was unrecorded in the disturbed habitat mosaic and bamboo zones. As with the previous species, Swynnerton's Robin must be considered management dependent.

\section{Iringa Akalat}

Vulnerable, member of a lineage which is disjunctly distributed within the Eastern Arc Mountains (S. lowei in the Udzungwa and Ukagurus, S. montanus in the West Usambaras), mainly on the forests of the high plateaux (Dinesen et al. 1993, Stattersfield et al. 1998). It was found only in mature montane forest and welldeveloped secondary forest at Uhafiwa, and is rather local, preferring dense undergrowth and thick vine-tangles in low parts of the terrain.

\section{White-winged Apalis}

Vulnerable, this disjunctly distributed bird appears to be strongly associated with Albizia canopies. These trees exist in glades in the mature forest (sometimes huge trees), in the disturbed mosaic habitat (many small trees in certain places) and are planted near villages. The White-winged Apalis was nowhere abundant but was seen, as a member of mixed feeding parties, in all these zones (and in largeleaved crowns of Anthocleista grandiflora at Uhafiwa, D. Moyer pers. comm.). Although the species has been eliminated locally (Tana River, Kenya), the Udzungwa population appears to be large and not particularly management dependent.

\section{Rufous-winged Sunbird}

Vulnerable, this bird is a strict endemic of the Udzungwa mountain block. It is narrowly associated with mature montane forest, at 1,600-1,750 m (altitudinal record), where it was found in nearly every herbaceous glade. Prefered food plants (Tecomaria capensis, Leucas densiflora; see also Jensen 1983) were found in many places in the disturbed zone, but were visited instead by Eastern Doublecollared Sunbirds Nectarinia mediocris and Collared Sunbirds Anthreptes collaris. The Rufous-winged Sunbird was clearly submissive to trap-lining Olive Sunbirds Nectarinia olivacea, and it may be unable to compete with sunbirds in more open and disturbed habitats. The species has not been seen in the somewhat disturbed forest further south in the Uzungwa Scarp Forest Reserve (C. Frimodt Møller, pers. comm.) or at Uhafiwa (D. Moyer and M. Rahner, pers. comm.). Its longterm survival will depend strongly on conservation of mature forest habitat.

\section{Tanzanian Mountain Weaver Ploceus nicolli}

Vulnerable, this species is rare and very local in the Eastern Arc Mountains, in tall forest with large amounts of epiphytic mosses and lichens. One pair was seen on two occasions, feeding (in a mixed species flock) in huge, epiphyte-laden trees at the margins of the forest glade shown in Figure 1a (E. Mulungu). The 
species has been seen once at Uhafiwa (M. Rahner, pers. comm.). It may be strongly management dependent.

The following species were not found in the study area and may be restricted to the north-eastern part of the Udzungwa mountains (which is ecoclimatically the most stable part of this highland, see Fjeldså et al. 1997): Udzungwa Forest Partridge Xenoperdix udzungwensis, Mrs Moreau's Warbler Sceptomycter winnifredae, Amani Sunbird Anthreptes pallidigaster, Banded Sunbird Anthreptes rubritorques and Green-headed Oriole Oriolus chlorocephalus (Jensen and Brøgger-Jensen 1992, Dinesen et al. 1993, 1994).

\section{Discussion}

Comparative studies of bird communities of undisturbed and disturbed forests need to cover a wide range of geographical areas before generalizations can be made about factors which determine the persistence of species and resilience of communities in human disturbed forests. The study design described here is simple and highly time efficient, and could therefore be useful in view of the logistical realities of studies in tropical forests. It should be emphasized that the principal advantage is not the sublisting but the approach of recording birds continuously while walking in a rather random way through the forest. This is highly time efficient (compared with point and transect data) and secures a broad coverage of the study area. Furthermore, it does not appear to be more biased than other observational approaches (judging from the very close correlation with data obtained by a more time-consuming method). The sublisting is in conflict with standard statistics for species richness estimation (e.g. Magurran 1988) but could be a practical guideline for those who otherwise provide only a total list of birds seen. The length of sublists needs to be modified according to the circumstances, e.g. 10-species lists in species-poor areas (see Poulsen et al. 1997).

Overall, the data presented suggest that the local bird community was strongly affected by habitat disturbance. The disturbed forest is rich in species but relatively low in genuine forest birds (Table 1). The bamboo forest had very few birds, possibly reflecting low botanical diversity as well as the acoustic disturbance of cracking and moaning sounds at the slightest breeze. The raised species richness in the disturbed zone as a whole is therefore not related to the presence of bamboo patches, but to the spatial heterogeneity of this zone.

The most remarkable aspect of the between-habitat difference in community structure (Figure $3 \mathrm{~b}$ ) was the abruptness of the change. Not a single Bar-tailed Trogon, Square-tailed Drongo, Swynnerton's Robin or Rufous-winged Sunbird was seen in the disturbed zone, not even in forest patches which were only 200$300 \mathrm{~m}$ away from continuous mature forest. Square-tailed Drongo and Rufouswinged Sunbird frequent light-gaps in the mature forest but may require that this feeding habitat is surrounded by well-matured forest.

The bird community of the disturbed forest was characterized by reduced numbers of specialized species of the forest understorey and forest floor. This agrees well with the findings of many other studies (Newmark 1993 for the East Usambara Mountains, and Laurance and Bierregaard 1997 for review). The sensitivity of larger canopy insectivores (Figure $3 \mathrm{~b}$ ) is more remarkable, especially 
since little attention has been given to this group in the literature. Only Canaday (1997) has reported a general decline in insectivores from forest edges and roads to the interior forest (in the upper Amazon area). He suggests that the most important factor could be the reduced amount of epiphytes in disturbed forest leading to reduced insect diversity. Tropical insectivores may be specialized because the selective pressure exerted by them make their prey increasingly hard to find and consume (Snow 1976, Rosenberg 1990). The importance of the large quantities of epiphytic lichens, mosses and ferns in primary forest has been much neglected in the discussion of effects of forest disturbance, which focused mainly on dead-wood and forest floor specialists. Pettersson et al. (1995) documented (for boreal forests) that differences in lichen abundance was the main determinant of the number and mass of arthropods. Nummelin and Hanski (1989) suggest a similar relationship in Uganda.

Ultimately, the supply of arthropod foods for birds may be related to the fractal geometry of the vegetation, and notably of the lichens (see André 1985, Gunnarsson 1992). Nadkarni and Matelson (1989) showed that epiphytes were involved in most foraging visits of Costa Rican forest birds, and Dinesen (1995, 1997) found that many greenbuls found most of their food in epiphytic moss. This also applies to Grey Cuckoo-shrike Coracina caesia and Usambara and Darkbacked Weavers Ploceus bicolor and other birds of mixed canopy flocks. In addition, the epiphytic mosses play a key role for the microclimate and water storage capacity of montane forests (Pócs 1974).

The selective pressure of mutualistic frugivory serves, unlike that of insectivores, to make fruits easier to find. Granivores and frugivores may profit by the appearance of certain opportunistic plants with high seed production or fruiting frequency (e.g. Rubus, Harumgana madagascariensis). Also mistletoes were much commoner in the thickets of the disturbed zone than in the primary forest. Restrepo et al. (1997) found, in Andean montane forests, that frugivores of disturbed forest fall into relatively few size cohorts, and I suggest that this could be an effect of a high supply of rather few fruit types.

Since species richness is often enhanced by the spatial heterogeneity of disturbed forests, range-size rarity scores may be a useful supplement to species richness and diversity indices in assessing the conservation implications of habitat disturbance. The reduced range-size rarity sum in the disturbed forest (Table 1) cannot be explained just from the appearance of some widespread nonforest birds, but reflects also a change in the ratio between endemic and widespread forest species. Local taxa representing widespread superspecies (Mountain Greenbul forms chlorigula, neumanni and usambarae, see Roy et al. in press; Chapin's Apalis Apalis (porphyrolaema) chapini; Thickbilled Serin Serinus [burtoni] melanochrous; Kipengere Seedeater Serinus [striolatus] whytii) seems rather indifferent to the human disturbance, but the truly independent and relictual species (Dappled Mountain Robin, Spotthroat, Iringa Akalat, Swynnerton's Robin, Rufous-winged Sunbird) all require well-matured forest.

The variation in community structure along the Eastern Arc Mountains seems to reflect a high rate of local loss of species outside the Usambara and Udzungwa Mountains (Fjeldså and Rabøl 1995, Cordeiro in press). However, as widespread species tend to fill the void in the smallest or most degraded forest patches, the total species richness inside the forest remains at a level of $42-50$ species. Prob- 
ably, the regional species pool was subject to strong climatic "extinction filters" since the break-up of the mid-Tertiary Pan African Forest (Axelrod and Raven 1978), and therefore represents a poorer but far more resilient community than the endemic-rich assembly of those few mountain slopes which may have been permanently forested since the Tertiary.

Fortunately, the attention to these forests, and the political will to conserve them, has been raised strongly through the arrangement of an Eastern Arc Conference on Biodiversity in Morogoro in Tanzania, $1-4$ December 1997. A strong interest in supporting rural development programmes with a strong conservation component has been expressed from several international donor organizations. The chances that the endemic birds of the Eastern Arc Mountains will survive are therefore now relatively good, despite the sensitivity of many species to habitat disturbance.

\section{Acknowledgements}

This study is part of a long-term research programme in the Eastern Arc Mountains, funded by the Danish Natural Science Research Council (grant no. 11-0390). I wish to thank David Moyer for his assistance with logistics, permits and agreements with the community of Masisiwe, and with valuable comments on the manuscript. Elia Mulungu and Ben Stephenson are thanked for their assistance throughout the fieldwork period. For good company, and for habitat data, I thank the botanists who have worked in this area, C. Frimodt-Møller, Vibeke Hørlyck, Dorthe Jøker, Grace Moshi and Josephine D. Mremi. For comments concerning species richness estimation I thank Carsten Rahbek, Tom Romdal and Nikolaj Scharff.

\section{References}

André, H. M. (1985) Associations between corticolous microarthropod communities and epiphytic cover on bark. Hol. Ecol. 8: 113-119.

Axelrod, D. I. and Raven, P. H. (1978) Late cretaceous and tertiary vegetation history of Africa. Pp. 77-130 in M. J. A. Werger, ed. Biogeography and ecology of southern Africa. The Hague: Dr. W. Junk.

Balmford, A. (1996) Extinction filters and current resilience: the significance of past selection pressure for conservation biology. TREE 11: 193-196.

Burgess, N. D., Fjeldså, J. and Botterweg, R. (in press a) The faunal importance of the Eastern Arc Mountains in Kenya and Tanzania. J. East Afr. Nat. Hist. Soc.

Burgess, N. D., de Klerk, H., Fjeldså, J. and Rahbek, C. (in press b) A preliminary assessment of congruence between biodiversity patterns in Afrotropical forest birds and forest mammals. Ostrich.

Canaday, C. (1997) Loss of insectivorous birds along a gradient of human impact in Amazonia. Biol. Conserv. 77: 63-77.

Cloudsley-Thompson, J. L. (1969) The zoology of tropical Africa. London: Weidenfeld and Nicolson.

Colwell, R. K. and Coddington, J. A. (1994) Estimating terrestrial biodiversity through extrapolation. Phil. Trans. R. Soc. Lond. B 345: 101-118.

Cordeiro, N. (in press) Preliminary analyses of the nestedness patterns of montane forest birds in the Eastern Arc Mountains. J. East Afr. Nat. Hist. Soc.

Danielsen, F. (1997) Stable environments and fragile communities: does history determine 
the resilience of avian rain forest communities to habitat degradation? Biodiver. Conserv. 6: 423-434.

Dinesen, L. (1995) Seasonal variation in feeding ecology of Shelley's greenbul in subtropical evergreen forests. Afr. J. Ecol. 33: 420-425.

Dinesen, L. (1997) Succeshistorier blandt afrikanske regnskovsfugle. Naturens Verden 1997: $178-186$.

Dinesen, L., Lehmberg, T., Svendsen, J. O. and Hansen, L. A. (1993) Range extensions and other notes on some restricted-range forest birds from West Kilomberu in the Udzungwa Mountains, Tanzania. Scopus $17: 4^{8-58 .}$

Dinesen, L., Lehmberg, T., Svendsen, J. O., Hansen, L. A. and Fjeldså, J. (1994) A new genus and species of perdicine bird (Phasianidae, Perdicini) from Tanzania; a relict form with Indo-Malayan affinities. Ibis 136: 2-11.

Fjeldså, J. (in press) Forest cover and summary endemism in the Eastern Arc Mountains of Tanzania, 1997. The Arc J.

Fjeldså, J. and Rabøl, J. (1995) Variation in avian communities between isolated units of the Eastern Arc Montane Forests, Tanzania. Gerfaut 85: 3-18.

Fjeldså, J. and Lovett, J. C. (1997) Biodiversity and environmental stability. Biodiver. Conserv. 6: 315-323.

Fjeldså, J., Ehrlich, D., Lambin, E. and Prins, E. (1997) Are biodiversity "hotspots" correlated with current ecoclimatic stability? A pilot study using the NOAA-AVHRR remote sensing data. Biodiver. Conserv. 6: 401-422.

Gunnarsson, B. (1992) Fractal dimension of plants an body size distribution in spiders. Funct. Ecol. 6: 636-641.

Hamilton, A. C. (1982) Environmental history of East Africa. A study of the Quaternary. London: Academic Press.

Jensen, F. P. (1983) A new species of sunbird from Tanzania. Ibis 125: 447-449.

Jensen, F. P. and Bregger-Jensen, S. (1992) The forest avifauna of the Uzungwa Mountains, Tanzania. Scopus 15: 65-83.

Laurance, W. F. and Bierregaard, R. O., Jr. (1997) Tropical forest remnants. Ecology, management, and conservation of fragmented communities. Chicago: Chicago University Press.

Lovett, J. C. and Congdon, T. C. E. (1989) Notes on the Ihan'gana Forest and Luhega forest near Uhafiwa Mountains, Tanzania. J. East Afr. Nat. Hist. Soc. 19: 30-31.

Lovett, J. C. and Pócs, T. (1993) Assessment of the conditions of the catchment forest reserves, a botanical appraisal. Dar es Salaam: Ministry of Tourism, Natural Resources and Environment.

Lovett, J. C. and Wasser, S. K. (1993) Biogeography and ecology of the rain forests of eastern Africa. Cambridge, U.K.: Cambridge University Press.

Lovett, J. C., Hatton, J., Mwasumbi, L. B. and Gerstle, J. C. (1997) Assessment of the impact of the Lower Kihansi Hydropower Project on the forests of Kihansi Gorge, Tanzania. Biodiver. Conserv. 6: 915-934.

Magurran, A.M. (1988) Ecological diversity and its measurement. London: Chapman \& Hall.

Maley, J. (1989) Late quaternary climatic changes in the African rain forest: forest refugia and the major role of sea surface temperature variations. Pp. 585-616 in M. Leinen and M. Sarnthein, eds. Paleoclimatology and paleometeorology: modern and past patterns of global atmospheric transport. NATO Adv. Sci. Inst. Ser. 282. Dortrecht: Kluwer.

McKinnon, J. and Phillipps, K. (1993) A field guide to the birds of Borneo, Sumatra, Java and Bali. Oxford: Oxford University Press.

Moyer, D. (1993) A preliminary trial of territory mapping for estimating bird densities in afromontane forest. Proc 8th Pan-African Orn. Congr.: 302-311.

Nadkarni, N. M. and Matelson, T. J. (1989) Bird use of epiphyte resources in neotropical trees. Condor 91: 891-907. 
Newmark, W.D. (1993) Tropical forest fragmentation and the local extinction of understory birds in the East Usambara Mountains, Tanzania. Conserv. Biol. 5: 67-78.

Nicholson, S. E. (1994) Recent rainfall fluctuations in Africa and their relationship to past conditions over the continent. Holocene 4: 121-131.

Nummelin, M. and Hanski, I. (1989) Dung beetles of the Kibale Forest, Uganda: comparison between virgin and managed forests. J. Trop. Ecol. 5: 349-352.

Pettersson, R. B., Ball, J. P., Renhorn, K-E., Esseen, P-A. and Sjöberg, K. (1995) Invertebrate communities in boreal forest canopies as influenced by forestry and lichens with implications for passerine birds. Biol. Conserv. 74: 57-63.

Pócs, T. (1974) Bioclimatic studies in the Uluguru mountains (Tanzania, East Africa). Acta Bot. Acad. Sci. Hung. 20: 115-135.

Poulsen, B.O., Krabbe, N., Frølander, A., Hinojosa, M. B. and Quiroga, C. O. (1997) A rapid assessment of Bolivian and Ecuadorian montane avifaunas using 20-species lists: efficiency, biases and data gathered. Bird Conserv. Internatn. 7: 53-68.

Prell, W. L., Hutson, W. H., Williams, D. F., Bé, A. W. H., Geitzenauer, K. and Holfino, B. (1980) Surface circulation of the Indian Ocean during the Last Glacial Maximum, approximately 18000 yr BP. Quatern Res. 14: 309-336.

Remsen, J. V. and Good, D. A. (1996) Misuse of data from mist-net captures to assess relative abundance in bird populations. Auk 113: 381-398.

Restrepo, C., Renjifo, L. M. and Marples, P. (1997) Frugivorous birds in fragmented Neotropical montane forests: landscape pattern and body mass distribution. Pp. 171-189 in W. F. Laurance and R. O. Bierregaard, eds. Tropical forest remnants. Ecology, management, and conservation of fragmented communities. Chicago: Chicago University Press.

Rosenberg, K. V. (1990) Dead-leaf foraging specialization in tropical forest birds: measuring resource availability and use. Pp. $360-8$ in M. L. Morrison, C. J. Ralph, J. Verner and J. R. Jehl, Jr., eds. Avian foraging: theory, methodology, and applications. Stud. Avian Biol. 13: 360-368.

Roy, M. S., Arctander, P. and Fjeldså, J. (1998). Speciation and taxonomy of montane greenbuls of the genus Andropadus (Aves: Pycnonotidae). Steenstrupia 24: 51-66.

Snow, D. W. (1976) The web of adaptation: bird studies in the American tropics. New York: Quadrangle, Times Book Co.

Stattersfield, A. J., Crosby, M. J., Long, A. J. and Wege, D. C. (1998) Endemic bird areas of the world. Priorities for biodiversity conservation. Cambridge, U.K.: BirdLife International.

Stuart, S. N. and Turner, D. A. (1980) Some range extensions and other notable records of forest birds from eastern and northeastern Tanzania. Scopus 4: 36-41.

Stuart, S. N., Howell, K. M., van der Willigen, T. A. and Geertsema, A. A. (1981) Some additions to the forest avifauna of the Uzungwa mountains, Tanzania. Scopus 5: 46-50.

Terborgh, J., Robinson, S. K., Parker, III, T. A., Munn, C. A. and Pierpont, N. (1990) Structure and organization of an Amazonian forest bird community. Ecol. Monogr. 60: 213238.

Usher, M.B., ed. (1986) Wildlife conservation evaluation. London: Chapman and Hall.

Williams, P. H. (1994) WORLDMAP. Priority areas for biodiversity. User version 3. Privately distributed computer software and manual, London, U.K.

\section{JON FJELDSÅ}

Centre for Tropical Biodiversity, Zoological Museum, Universitetsparken 15, DK-2100 Copenhagen, Denmark.

email: jfjeldsaa@zmuc.ku.dk 